\title{
correspondence
}

\section{Scientists in Argentina}

SıR,-My intention in writing this letter is to present another point of view regarding the position of scientists in Argentina. The letter written by 70 Italian scientists (July 22, page 253) has indeed surprised me.

I can remember that a law identical to the one which the Italian scientists referred to (Ley de Prescindibilidad) was passed two years ago by the constitutional government of Argentina. Under that law the Peronist government "released from duty", for "reasons of service" with no further justification, thousands of public workers from both scientific and nonscientific institutions. It is funny that at that time this group of Italian scientists did not air complaints. In this previous instance the Minister of Education of the Peronist government established very clearly a policy inspired by the criterion "who is not occidental and Christian is subversive". $\mathrm{He}$ repeated this criterion in several public talks, and again at that time no complaints from this group of Italian scientists were heard.

If scientists are interested in the advancement of science and not in politics then they should be impartial in judging the internal political situations that affect a scientist's work, especially in South America where these problems very frequently arise.

Subversion in Argentina could be found in every department and institution of the government. Subversives are not only those who plant bombs; they are also those who support the "guerrilla" in different ways, those who steal public money and those who use power to their own benefit. Argentina is now fighting for its survival against these groups and fortunately it is winning. Of course there may be some unjustified cases in which an innocent person is "released from duty", but many more innocent people lost their lives in bombings and terrorist acts.

I am completely sure that among the 550 scientists (according to the Italian scientists' letter) who lost their jobs there might be a few innocent victims. These mistakes are unavoidable; but there are also many more who have used their public jobs for political activism. I know personally a number of scientists who in many years have not published a single paper describing their research. Apparently there was no research which suited their personal interest; only politics.
During these many years the taxpayers paid their salaries.

It is not true that leftist people are being pursued in Argentina. Terrorists and guilty people, disregarding their political preferences, are being pursued. Numerous rightist members of the last government are now in jail because of mismanagement of public funds and robbery.

Because of the economic disaster produced by the previous government scientific institutions had to cancel their subscriptions to practically all scientific publications. Since I am temporarily in the USA continuing my research, I am perhaps one of the few Argentinian scientists who can read Nature and other publications in my field of interest. My colleagues in Argentina are not so lucky.

It is very difficult for Italian scientists to imagine the real situation in my country in all aspects (not only science) over the past four years. For that reason $I$ understand that it must be difficult for them to state an impartial opinion taking into account all the facts. Certainly it was an incorrect evaluation by these 70 Italian scientists that led them to write their uncritical letter to Nature.

Hugo Levato

Kitt Peak National Observatory,

Tucson, Arizona

\section{Alternative refrigerants}

Sir,-F. A. Cotton (Correspondence, March 25, page 280) attributes to us the suggestion that, "if we do not choose to give up refrigerators, we may have to continue tolerating atmospheric pollution by chlorofluorocarbons, even if we ban aerosol cans". In fact, we made no such suggestion, as any reader can verify (Correspondence, March 4, page 8). Our letter dealt with facts only, and we suggested that any decision to ban R-12 take those facts into account.

Cotton states that "refrigerators... normally release their refrigerant gas only when junked". Actually, the reverse is usually true; refrigerators are junked once their moving parts are so worn that they can no longer retain the refrigerant for a reasonable length of time. For this reason alone, Cotton's suggestions for laws promoting the recovery of refrigerant from refrigerators would not solve the problem of chlorofluorocarbon refrigerant release to the atmosphere.
W. J. Megaw (Correspondence, May 6, page 261) says a short release time of two years for a refrigerant is partly due to freeze drying applications and partly due to head and tail collisions of automobiles containing air conditioning systems. A Bureau of Domestic Commerce study (Economic Significance of Fluorocarbons, December 1975) does not identify freeze drying as a significant source of fluorocarbon emission. The one- to two-year replacement time for automobile refrigerants is again due to leakage; automobile air conditioners are of necessity light weight and are subjected to vibrations and temperature extremes of the automobile engine. Automobile air conditioners use R-12 exclusively.

The BDC study attributes R-22 as being $30 \%$ of the total refrigerant used, not $50 \%$ as Megaw states. R-22 is used primarily in building air conditioning where low temperature is not required. Commercial and home refrigerators and freezers use R-12 almost exclusively. R-12 and R-22 are not interchangeable in existing refrigeration equipment, valued at $\$ 100,000$ million, because they have quite different physical properties. Total replacement of R-12 and R-22 would require redesigning many refrigeration systems. These refrigeration systems will necessarily be more expensive since they must operate at higher pressures. Difficulties posed by compressors burning out have thus far prevented the use of R-22 in refrigerators and freezers. This design problem is a consequence of the high heat of compression, low density and high specific heat of R-22.

Model calculations by Sze and others indicate that an additional two years of fluorocarbon production will lead to $0.1 \%$ additional ozone reduction. This assumes an infinite troposphere lifetime for R-11 and R-12, that is, a maximum reduction in the ozone. We believe that an immediate ban on refrigerant or aerosol propellent uses of $\mathrm{R}-11$ and $\mathrm{R}-12$ would be unwise in view of present uncertainties in the theory. The two-year moratorium requested by industry to continue research programmes that began over a vear ago. and which have already been fruitful, is very reasonable.

ThOMAS J. LeCK

JOHN W. BIRKS

School of Chemical Sciences, University of Illinois, Urbana 